\title{
Syariah Judge's Perspective on Community Service Order
}

\author{
Nurbazla Ismail ${ }^{1} \&$ Mohd Al Adib Samuri ${ }^{1}$ \\ ${ }^{1}$ Department of Syariah, Faculty of Islamic Studies, National University of Malaysia, Malaysia \\ Correspondence: Nurbazla Ismail, Department of Syariah, Faculty of Islamic Studies, National University of \\ Malaysia, Bangi, Selangor, Malaysia. Tel: 60-13-294-7862. E-mail: nurbazlaismail@gmail.com
}

Received: April 4, 2014 Accepted: June 26, 2014 Online Published: July 24, 2014

doi:10.5539/ass.v10n16p71

URL: http://dx.doi.org/10.5539/ass.v10n16p71

\begin{abstract}
Community service order is a new form of punishment to be widely applied in the Syariah courts particularly in Malaysia. Its implementation seems fit charging for light offences or first offences. However, there are several issues begging for analysis before implementation can be proposed and those issues are; the absence of relevant provisions mentioned on the subject matter in the Syariah Court, to what extent community service order can be categorized as a takzir (judge discretion) punishment, and the issue of association between the perspective of syariah judge and maqasid syariah on that matter. Thus, the objectives of this study; to analyze the concept of community service order according to maqasid syariah, to explain the perspective of syariah judge in that respect, and to identify the coordination of syariah judge's perspective with maqasid syariah. This is a case study based on qualitative research approach. Data collection is by the methods of document analysis and semi-structured interviews, while data analysis by thematic and descriptive methods. The study finds that most of the syariah judges conform to the opinion that community service order can be categorized as a takzir punishment. A takzir punishment fits the requirement of maqasid syariah vis a vis giving evidence that community service order is based on the objective of punishment in Islam (maqasid syariah). Therefore, this study is important to support the argument for the construction of a specific guidance for the implementation of a community service order punishment in the Malaysian Syariah court.
\end{abstract}

Keywords: community service order, syariah judge's perspective, maqasid syariah

\section{Introduction}

Syariah Court in Malaysia has jurisdiction relating to Syariah criminal offences based on the provisions of section 2, Syariah Courts (Criminal Jurisdiction) Act 1965 (Revised 1988) (Act 355) which states that the offence can only be attributed to those who are Muslims. The term "offences" is only mentioned in the Ninth Schedule of the Federal Constitution in relation to offences against the precepts of Islam only. While punishment for such offences is also imprisonment not exceeding three years or a fine not exceeding five thousand ringgit or with whipping not exceeding six strokes or with any combination there of.

Based on the provisions set out, it is clear that there is no mention of provision related to community service order in the Syariah Court. Therefore, consideration should be given to establish a specific provision or to make clear of existing provisions of such order. As the implementing body of the Islamic justice system in Malaysia, opinions and perspectives of the Syariah judges with respect to this punishment should be reviewed.

\section{Method}

This study is conducted to examine community service order according to Islamic law and the prospect of execution of the sentence in the syariah criminal justice system of Malaysia. Therefore, this research will discuss the perspective of Syariah judges against the community service order so that the finding supports the construction of a set of guidelines for the implementation of this punishment in the future.

Data are collected through semi-structured interviews on nine of the Syariah High Court Judges and five Chief Registrars of the State Syariah Court. Syariah court is the implementing body for the proposed punishment. Since there are fourteen Syariah courts in Malaysia, only five states are chosen based on zoning of those states are Pahang, Johor, Selangor, Federal Territory and Kedah. While two judges of the High Court or one Chief Registrar chosen because they had tried such cases or in the midst of trials on syariah criminal cases related to the subject of the study. 


\section{The Concept of Community Service Order}

To discuss the problems and answer the first question of this study which is the underlying concept of punishment for community service order? Whether there are similar theories being debated by the Islamic jurists? Thus, the discussion in this sub-topic debates on the views of the Islamic jurists with regards to takzir punishment said to be the underlying concept of punishment for community service order.

In general, community service order can be categorized as a takzir. Takzir punishment stands within a broader scope and in determinant of the types of punishment as prescribed by Islam (Bahnasi, 1969, p. 171). This means the takzir may be interpreted in accordance with the opinion of the Islamic jurists based on their respective ijtihad. However, from the practice of the Islamic legal system, the power to determine takzir punishment is given to the judges to choose the most reasonable sentence depending on the circumstance of the offender (Abu Rukhiyyah, 2010, p. 299; Yunus, 2003, p. 39; ${ }^{\mathrm{c}}$ Awdah, 2009, p. 122) with a goal to safeguard the public interest (Yunus, 2003, p. 39; ${ }^{\mathrm{c}}$ Awdah, 2009, p. 102).

Judges also can reduce the sentence or impeach heavier sentence given consideration (Abu Rukhiyyah, 2010, p. 300; Yunus, 2003, p. 39). This is due to the broader scope of takzir punishment with no limits imposed. Under the punishment of takzir, the judge can also grant pardon to the offence committed by the offender in totality or partially if there is a maslahah for doing so (Abu Rukhiyyah, 2010, p. 300; ${ }^{\mathrm{C}}$ Awdah, 2009, p. 103). Therefore, it is not offensive for the judge to decide for the sentence of community service orders to criminal offenders if it is deemed appropriate.

\section{Community Service Order from Maqasid Syariah Perspective}

Following the above, the question arose, to what extent the sentence of community service order can achieve the primary purpose of punishment? The Islamic jurists have so often debated on this purpose. It is referred to as maqasid syariah which means the objective of Islamic law. To answer this question, the next topic will discuss in more detail the objective of Islamic punishment basing on the principle of maqasid syariah and to what extent is the capability of community service orderin achieving the maqasid syariah.

Sharia is apparently based on the laws, and the rules meted out are meant to safeguard the public interest and to avoid harm. This matter has been debated by majority of the Islamic jurists such as ${ }^{\mathrm{C}} \mathrm{Izz}$ bin Abd al-Salam, Ibn Taymiyyah and Ibn Qayyim al-Jauziyyah (al-Zaidan, 2000, pp. 88-89). Each punishment prescribed by Islam contains certain wisdom and bring good retributions to the persecuted offenders and even in some cases, the good retributions reach down to their family and the public. For example the sentence of stoning of adulterers in the case of hudud. In addition to punishing wrongdoers, execution of punishment sends out reminders to the community who witness the execution. This is the so-called punishment objective (maqasid syariah) to safeguard the public interest (Amran, 2012).

Maqasid shariah carries the meaning of objective or purpose placed by Islamic law in setting a sentence (Auda, 2010, p. 246). It also means the maslahahs to salvage mankind in this worldly life or the hereafter. In summary, maqasid syariah is the goals to be achieved by the tenets for the benefit of mankind (Basri, 2011). Any occurance of changes in laws with time and place is none other than to protect the public interest ( ${ }^{c}$ Awdah, 2009, p. 120), giving benefits (Abu Zahrah, t.th, p. 28), and avoiding mischiefs. As the word of Allah SWT in the Qur'an, (Yunus, 2010, p. 57) which means: "O people! There has come an admonition to you from your Lord and healing of hearts, and guidance and a mercy for the believers".

The above verse explains that nefarious or criminal acts can be effectively prohibited by implementing the Islamic law. The maslahahs of mankind cannot be attained by doing evil but rather good deeds will be followed by maslahah. Furthermore, Islamic fuqahas argued that the subsist of syariah is to safe guard the maslahah of mankind, but in the event of a crime, then the punishment for the offence is mandatory.

To implement these punishments, there are many ways to be used that is either in the nas of al-Qur'an or al-Hadith. Punishment can also be implemented by a fair government who seeks guidance from al-Qur'an and al-Hadith. However, if there is no evidence found in neither in the al-Qur'an nor in the al-Hadith, the punishment then can be made analogous to the punishment in the legal text. In the real sense, the government is obligated to carry out the sentence on the basis of safeguarding the public interest (Abu Zahrah, t.th, pp. 28-29). In this context, takzir sentence provided in the nas is vast and diverse. Thus, community service orders included in the takzir punishment is intended to keep the public interest by doing good deeds. Therefore, the punishment is genuine and fulfills the requirement of maqasid syariah in total.

Besides, the punishment meted out to be adhered to by the judge as the command of Allah as a retribution for committing a criminal offence (Bahnasi, 1980, pp. 107-108). Every offence committed by a man should be 
reattributed with punishment accordingly. This punishment needs to be carried out so as to be a lesson to the people who have never committed such crimes. Thus, the punishment meted out by the judge must serve the purpose of safeguarding the public interest based on the principles of maqasid syariah. Moreover, the objective of punishment is also to safeguard freedom of the individuals. Freedom would mean the freedom of thought, freedom to express an opinion, or freedom of belief and religion. Individual freedom meets the requirement of maqasid syariah to preserve the soul and mind. Thus, will subsequently safeguard the maslahah of the society.

According to Abu Zahrah (t.th, pp. 77-78), Islamic punishment must meet four requirements, first to safeguard the public interest, and not to satisfy the desires and enthusiasm of the judges or others. Second, a sentence that is beneficial to the community. Third, a sentence that is reasonable between punishment and the crime committed, not to be wrongly prosecuted and punishment must not be over-emphasized of the crime committed. Fourth, equality and equity for all. These requirements almost meet the totality of maqasid syariah i.e. the preservation of religion, soul, intellect, lineage and property.

Shedding lights through various debates, it can be concluded that the main objective of punishment in Islam is to maintain public interest based on the principles of maqasid syariah i.e. to preserve religion, soul, intellect, lineage and property. Therefore, the sentence of community service order can be said to meet all requirements of the maqasid syariah. This is because the sentence may be charged to offenders who have committed criminal offences, such as moral crimes of behaving indecently in public (Rahman, 2013). This sentence specifically charge only the individual offender, however the community service order can be carried out within the community itself for example, picking up litter in the city. This means, the community will be indirectly involved as witnesses to the implementation of sentence meted out. Thus, simultaneously the punishment will preserve the religion of Islam by proving that the Islamic punishments are being implemented.

Furthermore, safeguarding the soul of the individual offender and preventing him from being further deeply involved in more serious offences when incarcerated and influenced by other inmates (Amran, 2012; Abdul Ghani, 2012). Besides, this sentence can preserve the soul of the offenders by charging punishment that can bring remorse and nurturing one's soul (Abdul Ghani, 2012). This sentence can also be perceived as safeguarding for the offenders and the community as someone who witnesses the implementation of this sentence would not have the courage to commit crimes. Furthermore, these kinds of penalties can be embarrassing to anyone (Rahman, 2013), thus the individual will prohibit any of the family members from being involved in the least petty criminal activity.

In addition, this sentence can protect the offender's property, his families and the nation. This is because community service activities do not cost the offenders any money unlike a fine. The offender only has to do community work as a payback or retribution for the offence committed. Offender's family does not have to provide financial assistance and in fact on the contrary may be paid for the social activities they undergo. While the government may save lots of money for not having to pay the cost of keeping a prisoner or to pay the cost of imprisonment of offenders (Sharifuddin, 2012).

Therefore, the discussion has clarified that community service orders meet the objective of punishment in Islam (maqasid syariah) and can afford to give good impact to both the offender and the society (Abdul Ghani, 2012). Therefore, this punishment should get the support of all parties so that it can be implemented in the justice system of Malaysia, particularly in the Syariah Court.

\section{Discussions}

\subsection{Syariah Judge's Perspective with Respects to Community Service Orders}

The findings of this study will describe the level of acceptance of the syariah judges in categorizing community service orders as takzir punishment. Most participants interviewed agree that the community service order can be categorized as a takzir punishment. Some of their responses are as the following:

Participant 1: "... takzir. To me, I will have to agree. That is, the punishment is under the category of takzir according to Islam. It is takzir. Meaning to say that it is up to the ruler to decide on the sentence ruling. Indeed, it is categorized as takzir. It will not go to any other category..."

Participant 2: "... the punishment prescribed by Allah, in the al-Qur'an or in the hadith, the sunnah of the Prophet. In addition to that, the penalty is called takzir penalty. So, if we want to include this community service, as a takzir ..."

Participant 3: "... so, in terms of this community service, we can categorize this Islamic law as takzir ..."

Participant 4: "... it is possible, agreed. It is better when associated with community service can be categorized as 
a takzir sentence and it is a good form of punishment ..."

Participant 6: "... right. Agreed. Because this community service, it is takzir punishment ..."

Participant 8: "... I totally agree. Indeed very much agreed. We can categorize it as a takzir punishment ..."

Participant 9: "... So, to say this community service as takzir, then takzir it is. In fact, it is takzir in the first place. So, what is going to be implemented, it is takzir. And indeed if there exists, or we practice the enactment of fined offences, with respect to those offences, we charge them with community service that is takzir..."

Takzir offence is an offence not in the al-Qur'an or al-hadith to describe penalty measures (Abu Zahrah, t.th, p. 75 ; ${ }^{c}$ Awdah, 2009, p. 102), but the matter is referred to as an offence or is condemned on the offender. Takzir can also be applied to the offences established under the syariah law, but due to inadequate evidence (Bahnasi, 1983, p. 181), the absence of witnesses, weak evidence, or witness withdrawing testimonies (Abdul Rahman, 2007, p. 22), thus the original sentence cannot be imposed on the perpetrator, and rather takzir is charged according to what the judge thinks appropriate (Bahnasi, 1983, p. 181). In other words, takzir is a criminal offence or non-criminal offences that do not fall into the category of hudud and qisas (Abdul Rahman, 2007, p. 22). This is consistent with the findings of this study:

Participant 7: "... To me, he can. Because of takzir, the judge would not determine on the sentence unless if it is hudud. For hudud, the judge will mete out the sentence. But, other than that, it is called takzir..."

Participant 9: "... It is takzir, one that is not found in the al-Qur'an or al-hadith. So, any of the offences mentioned in the al-Qur'an quoted as such, that would be hudud, qisas etc. So, anything else not mentioned is takzir. So, takzir would be any form of punishment meted out by the government that is not mentioned of its provision in al-Qur'an or al-hadith..."

Participant 10: "... Meaning that, takzir is anything that relates to those that are not mentioned in the syariah law that is the law..."

Takzir punishment covers a wider range beyond the scope. Such characteristic is due to the public interest when deciding for punishment of rare circumstances ( ${ }^{\mathrm{c} A w d a h, ~ 2009, ~ p . ~ 102 ; ~ B a h n a s i, ~ 1969, ~ p . ~ 171) . ~ S y a r i a h ~ l a w ~ d o e s ~}$ not define the constraints and limitations of punishment of takzir offence to be imposed by a judge when deciding on the sentence (Bahnasi, 1969, p. 171; ${ }^{c}$ Awdah, 2009, p. 102). The punishment meted out according to what is ordered by the judge based on his wisdom and ijtihad (Bahnasi, 1983, p. 181).

This means, takzir sentence shall be interpreted in accordance with the opinion of the fuqahas based on their ijtihad (Abu Zahrah, t.th, p. 75). However, from the view of application in the Islamic legal system, the power to determine takzir sentence is given to the judge (Abu Zahrah, t.th, p. 75) to choose a reasonable sentence judging from circumstances of the offenders (Abu Rukhiyyah, 2010, p. 299; Yunus, 2003, p. 39; ${ }^{\circ}$ Awdah, 2009, p. 122) and is intended to safeguard the public interests (Yunus, 2003, p. 39; ${ }^{\mathrm{c}} \mathrm{Awdah}, 2009$, p. 102). Therefore, the judge may mete out a sentence based on the ${ }^{c} u r f$ or the present customary punishment. However, it is still subject to the guidance of the al-Quran dan al-Hadith to ensure totality and effectiveness of punishment (Noor Huda, 2013).

Participant 1: "... it is takzir. Meaning to say it is up to the government to decide on the punishment ..."

Participant 3: "... takzir is any penalties that may be created by the government other than hudud and qisas. It is confirmed in the al-Quran, the hadith. It is confirmed with qisas, and takzir. But for takzir, any appropriate punishment..."

Participant 4: "... the reason for takzir, any sentence that is deemed reasoble by the government or local authorities for the purpose of educating that person, in any such form..."

Participant 5: "... This is all at the discretion of the judge. Depending on the judge, how far his knowledge is on the matter and how far he wants to apply it ..."

Participant 7: "... So, takzir is subjective and follows the discretion of the judge, of course in terms of the interpretation..."

Participant 8: "... of course. Because takzir is very diverse. According to fiqh it is true that it all depends on how the judge thinks, as the given power. Meaning to say, up to the wisdom of the judge ..."

Although the judges can impose takzir punishment according to their respective discretions, they are still bound by the provisions of the existing law. The relevant provisions of this community service order should also be mentioned in order to guide the judges in deciding on the sentence. If a sentence befits the law, then it can be categorized as a takzir sentence. If there is a provision of the law, the court may exercise this sentence and it can be categorized as takzir sentence. This is because some judges will consider the sentence to be decided as one 
under his jurisdiction. Otherwise, they can be held liable. This is supported by the findings of this study:

Participant 5: "... Depending on the judge, how much he knew and how far he wanted to use. If the judge has no knowledge, then he may not use or may use then it turns out to be inaccurate. Because we understand that in the context of Islamic law, if the punishment is not based on the given power, it is wrong ..."

Participant 6: "... since community service is a takzir sentence, yet the law should be clearly stated. It is not the truth or even a power open to the judge to issue such orders without first have clear reference to the jurisdiction. Should be clearly stated ..."

Participant 10: "... Meaning, takzir is when it relates to punishments not mentioned in syarak, the Islamic law. With community service, it is hard to say. If it befits the law, then it can be included. Meaning to say, it can be called as takzir. If it befits the law then it is ok. Which means that, the court will decide based on the laws. If it befits the laws then takzir can be applied..."

However, there are also participants who disagree to categorize community service order as a takzir punishment. In their view, community service is a second chance given by the judge to the offender before the verdict of imprisonment or fine or whipping.

Participant 5: "... for the punishment of takzir, in the context of the current law, it is not takzir, at least to my opinion. Instead, it is more of a second chance. Sometimes, most judges like myself, I will not convict a person guilty if the bond conditions are met.It is more to give a second chance before the takzir sentence is imposed ..."

According to him, if community service order is categorized as takzir, the laws will be the first to mete the sentence as an alternative.

Participant 5: "... If we categorize takzir as to include community service, why is it not chosen as one of the sentence alternatives ..."

\subsection{How Far Does Community Service Order Meet the Objective of Punishment}

Punishment is a retribution imposed to safeguard the wellbeing of the community from sin forbidden by Allah ('Awdah, 2009, p. 455). It is not something that is intentionally created without reasonable cause and reason, but it is a necessity to guarantee the protection of mankind. Thus, a sentence prescribed by Islam should have a purpose or specific goal or objective. This is to ensure that the implementation is able to safeguard the wellbeing of the society.

Participant 1: "... it is indeed in Islam, the purpose of punishment? What is the purpose of sentence? Therefore, in Islam there are goals and objectives of punishment..."

Participant 4: "... the purpose is to have to look at the wisdom of such sentence, ${ }^{c} u q u b a h$, it has a character. ${ }^{c}$ Uqubah is to achieve the purpose of gharar, the sentence meted out. Do not decide on punishment that serves no purpose..."

Participant 5: "... for a reason to do something, to me, is first we must understand the concept and principles of the sentence. Sometimes we say, what men think is good, but I believe that the best is what Allah has preordained for us..."

As mentioned in Qur'an (al-Zalzalah, 1999, pp. 7-8), every good or bad deed will definitely have its reward and reckoning either in this world or the hereafter. The verse explains that anyone who makes even the smallest charity will be accounted for by Allah. The same goes for anyone who makes even minor crimes, will still be accounted for by Allah and will be written in the sheet of actions. None will escape from the sight of Allah. Thus, it is clear that every evil there will be punishment and persecution.

Participant 1: "... and all wrong doings even as small as atom, there is the retribution. It is mentioned in the al-Qur'an..."

Therefore, the purpose or goal of punishment should be identified so that the sentence passed will serve the purpose for such sentence created. The objective of punishment is much debated by the Islamic jurists and many contemporary researchers. The purpose of sentencing is to reform (islah) (al-Zaydan, 1998, p. 36; Zaini, 2008, p. 4; 'Awdah, 2009, p. 455; Abu Rukhiyyah, 2010, p. 297) and rehabilitate individual offenders (O'leary, 1987; ${ }^{c}$ Awdah, 1989; Altschuler \& Armstrong, 2001; Smith \& Smith, 2005; Allen, 2008) thus creating inner peace of the offenders (al-Zaydan, 1998, p. 36). It is one of the recovery methods carried out on the offenders (Zaini, 2008, p. 3) to become useful again to the society. Besides, penalties are enacted to keep peace and harmony (al-Zaydan, 1998, p. 36), to protect and to safeguard the community system (Zaini, 2008, p. 4).

Participant 1: "... if possible the punishment meant to rehabilitate..." 
Participant 6: "... the court can see that this community service is one punishment that may bring awakening or rehabilitate ..."

Participant 6: "... methods of better rehabilitation..."

The findings are in line with results of studies done in the United Kingdom carried out to consider the implications of existing strategies of community service order program. This program discusses the strategy that is not consistent with claims to improve skills in the implementation of community service work. The study found that most respondents indicated that the primary purpose of job selection was rehabilitation (Johnson \& Ingram, 2007). This is because the justice system is seen as a requirement to comply with the principle of protecting the community and build the confidence of the community and improve the community and service approach as to create stronger and more effective society.

While the study by Harris et al. (1989) shows that the majority of respondents stated that the objective of treatment or assistance was the most important objectives of community supervision. Similar study by Diggs $\&$ Pieper (1994) states that the primary purpose of community service is to treat offenders. Treatment is intended to help improve and change the offenders for the better and to be able to contribute to the society (Harris et al., 1989). This proves the beneficial aspect of the sentence of community service order.

Participant 6: "... community service order is a good suggestion for improving a person ordered to undergo such order..."

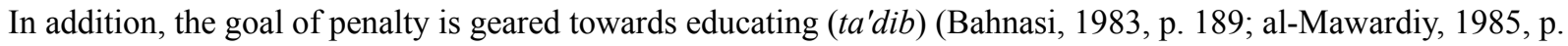
293; 'Awdah, 1989; Abu Rukhiyyah, 2010, p. 297; Noor Huda, 2013) and punishing (tahzib) the offender as the right of the society to be compensated for the oppression inflicted upon them (Bahnasi, 1983, p. 189; Abu Rukhiyyah, 2010, p. 297; Allen, 2008). This is consistent with the result of this study stating the objective of punishment according to the participants under this study:

Participant 1: "... because we stick to the goal to educate the society ..."

Participant 4: "... this takzir, any sentence that deems good to the government or local authorities for the purpose of educating the people, in whatever forms..."

Participant 5: "... Because we have to recall, the principles of takzir punishment. Needless to say of indifference between hudud, and takzir. The principle is inzar, ta'dib. Would all this community service sentence rendered as ta'dib? ..."

Participant 5: "... Meaning, that's the reason why the execution has to be among the people. Ta'dib, to educate. Educate whom? The person and the public. Including the court itself. That is the reason why it has to be carried out in front of many people, it educates ..."

Participant 6: "... the method of community service is not judgmental. The method of community service, a method of educating. Directly educate someone, practically. And it is education..."

Participant 6: "... for youthful offenders, it's good, it's good they undergo community service, as a way to educate, to educate them ..."

Participant 8: "... because men do not like to be punished. If they are punished, they will become worse. That is the reason why the Messenger, when he invited his companions to do good, he did not come with threats only, not with tarheeb alone but with targheeb to give boost to their spirits, to encourage ..."

This finding has been proven by a research done by Leibrich et al. (1986) with regards to community service. Respondents were asked to comment on the purpose of the community service sentence and its accomplishment is evidenced of its purpose to punish offenders with a fair punishment (O'Leary, 1987). Punishment is also meted out to judge anyone who commits a sin against others and inflict those harms (al-Mawardiy, 1985, p. 293).

However, there were participants who said that incarceration can also educate. This is because in prison there are also trainings provided to the criminals but the sort of education in prison is different due to the constraints of environmental conditions without community engagement.

Participant 6: "... even in the lockup can also be educating, in prison. Being in jail for three months and provided with trainings but of course in prison, the training is not the same if the offender is to engage directly with the community..."

Moreover, the purpose of punishment is also to build a sense of self-awareness to offenders and to test their faith, obedience and submission to Allah (Noor Huda, 2013). Punishment can motivate men to obey the rule of Allah (Zaini, 2008, p. 2; ${ }^{\mathrm{c}}$ Awdah, 2009, p. 455) and direct them to not go astray from the right paths ( ${ }^{\mathrm{c}}$ Awdah, 2009 , p. 
455). At the same time, this sentence can serve as a lesson to the perpetrator and the community so as not to repeat the same mistake (Abdul Halim, 2005, p. 174; Zaini, 2008, p. 3; Noor Huda, 2013). The finding is supported by several participants as follows:

Participant 2: "... It is the basis of takzir sentence, i.e. it is not punitive. It is a form of lessons and warnings. That is the basis of takzir sentence. So, if it is said to, first bring awareness to the perpetrator, or to warn him not to repeat the offence. Meaning to say, it is sufficient, right ..."

Participant 4: "... community service is important rather than if we send him to a place, where he gets worse. Go to jail, they cannot do community service ..."

Participant 5: "... Why use inzar? Warning is for others and oneself. Meaning, that is why it needs to be done among the people ..."

However, if the offence is repeated, community service is no longer appropriate to render as lessons and warnings. This is because a person who repeats the same offence means the punishment is not effective for him. Thus, the possibility of other penalties should be imposed on such offenders.

Participant 2: "... If the community service, not for him then, won't work. For example, he might have so often times committed similar offence, and that's the first time he is brought to court, as an example. So, perhaps in terms of awareness, educate, may not be sufficient, no effect ..."

Although the community service order can be said to bring good lessons and effects on the offenders, it can't be assumed that imprisonment, a fine and whipping as ineffective. Neither to assume that such penalties as cruel and inconvenience the offenders. Effectiveness of punishment is specific on each case.

Participant 5: "... We cannot make presumption that the existing punishments are not enlightening, or any of these punishments cruel, that must not be. It is all depending on the case ..."

Community service orders may bring awareness and remorse on the mistakes done by offenders. Awareness can change them to become good. This is based on the result of study from interviews of several participants in the study as the following:

Participant 4: "... we say, we mete out this sentence for awareness so that he will be more responsible. So, it means that our goal is for him to be responsible, aware of his responsibility and at the same time, for him to continue living. Meaning to say, community service is better because we sentence him so that he realizes of his obligations to the society and the society's perception of such offence ..."

Participant 6: "... it is good that they undergo community service, to give them awareness. Maybe they have no religion close to their hearts before this in their lives, but now they have become closer to religion, to understand their errors, why they committed the offences before this ..."

Participant 8: "... it will be touching, to give him awareness..."

Participant 9: "... there are also instances of possibilities that they have never been to the mosque, never done it before, then all of a sudden to be punished like that, that brings him awareness, awakens him. There are instances like that. .."

Participant 9: "... And if by serving the community is more effective, more remorseful, effective in scaring them, why aren't we doing it? It is one very good thing to do..."

Participant 10: "...community service, means, the very least, the concept is to create awareness to the guilty parties ..."

However, the effects of awareness of the offender depend on their hearts and souls. If Allah blesses their souls to realize, then they will realize the mistakes done. Otherwise, they will not see the wrongdoings of their offences. Obviously, everything depends on the will of Allah to determine the effect of a sentence that meets the goal of punishment.

Participant 7: "... But how can we tell what are in their hearts. Sometimes when you do that, they change. Because Allah decides on any change of hearts. It is not necessary that there'll be dejections when we apply it. Sometimes, when imprisoned, then comes awareness. Perhaps, he did it, there'd be awareness ..."

Participant 8: "... If Allah wants to give him guidance, then he will be guided ..."

Participant 8: "... we cannot assume and be assured that all the prostitutes want to go to hell. No. We wouldn't know when Allah would change them to be better than us; the paradise for them is higher than our paradise ..."

Nonetheless, the impact of awareness can also be seen from the offender's change of behavior. This is because 
community service is capable of forming a good character in terms of spiritual or religious beliefs. If he turns toward goodness after serving a sentence, it can be concluded that the sentence brings awareness to him. Furthermore, it's proven that the goal of punishment can be achieved as required by Islam in general, and the Syariah courts in particular. This is supported by a number of participants as follows:

Participant 1: "... but at the same time, if you add a new activity in the context of how many hours he has to attend sessions of religious classes, group sessions, counseling sessions. It will work more effectively. It will be touching on his personal character development. That is the aspect that we want. Meaning, the purpose of punishment. Let's say we send them for community service, the effect will be more, at least to my view... "

Participant 4: "... this community service is more to what? Moral development, awareness. Shaping him to be responsible and be a person of a good character and at the same time, to energize him into becoming a person of good quality, spiritually, to care for the elderly... "

Participant 8: "... but we at the syariah court is actually, having the desire to change people, for the better, in terms of moral..."

Participant 10: "... The sharia court is meant to, create awareness among the guilty party. We are not saying that, the service is to punish or torture. What's important is his awareness. It's part of our missionary attitude. Meaning to say, he can turn back to the original path, to the right path, right ..."

Participant 10: "... to make them more aware, to come back to the basic truth, that is what I mean. The consequences of their wrongdoings, perhaps a provision of marriage, to abandon children out of wedlock. So, with this community service, when people give that look at him, he will repent, to not repeat the mistake, right ..."

Furthermore, the goal of punishment is also to prevent and protect people from doing bad deeds or damage (Abu

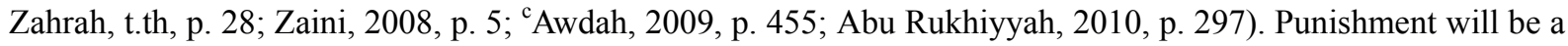
painful experience to the perpretrators. This is because, there won't be only physical pain but also emotional stress due to public humiliation and shamed (Zaini, 2008, p. 2). Prevention will only be successful through the implementation of such sentence, striking fears in the society thwarting them from committing such crimes. For the criminals on the other hand, the pain of punishment inflicted on him would thwart him from recommitting the crimes (Zaini, 2008, p. 5; ${ }^{\mathrm{c}}$ Awdah, 2009, p. 455).

Participant 9: "... For me, personally, I support the sentence of community service. To me, the focus would be in accordance with our laws. Because if we look at our laws, the real goal is for preventive purposes..."

The finding is corroborated by the results of research by Palmer et al. (2009) who states that the purpose of implementation of a community service order is to help offenders avoid recidivism through the development of attitudes and behavior. This is because the offence committed can be associated with the mindset of the offenders. Therefore, the development of a positive attitude through community service activities can help offenders to curb them from repeating the same offence.

While the finding of research by Harris et al. (1989) claims that community service orders are meant to protect and care for the community. This is because such execution of sentences is capable of showing that the offenders are given punishments that are embarrassing for some people. Therefore, the society will not have the guts to commit such punishable offences. In addition, there are community outreach programs that provide environmental conditions in building societal awareness of the offenders (Smith \& Smith, 2005). At the same time, the offenders can contribute something beneficial back to the society.

Participant 1: "... then there is something worthwhile that he can give back that is to give back to the community ..."

Participant 2: "... As I outlined earlier. Meaning, there are four purposes. Meaning to ensure that, first, we want to safeguard in terms of the community itself, right ..."

Clearly, to achieve the goal of punishment is to return to religion. Because, for each mistake charged stems from the individual's inner self, i.e. the heart. If the outer part is damaged, it is the reflection of what's in the heart. Therefore, to improve the outside must go back to one's inner soul and use the method than can change their heart desires to be good again.

Participant 5: "... Because we have to remember, we have to come back to the principles of religion ..."

Participant 8: "... so, these kinds of people, those with broken faiths, it boils down to faith. Once faith is broken, there's no belief in Allah, lose confidence of the life brought by the Prophet, the one great thing is gone. Thus, with a heart full of faults, faults will produce faulty practices, wrongdoings. Therefore, to destroy falsehood, not 
by violence, lest committing wrongdoings. To correct falsehood is not by falsehood but with lights. To make darkness go away is with light. To get rid of darkness not by darkness ..."

Among the ways of doing it is by using kindness that can be beneficial both to the offender and the community alike. This is because the possibility of punishment by way of kindness can bring remorse to the offenders directly and indirectly brings awareness to the community. This is consistent with the element of the community service carried out to bring good.

Participant 8: "... so, such goodness, we want goodness to be served. Thus, this community service, its main point is the goodness of that person. The goodness he brings to others. Not to punish him. But, that's what I understand ..."

Participant 8: "... so, meaning that we today, prefer to solve problems with punishing people. We do not use a better way. Truly, any form of punishment should not badly affect him, but the kind of penalty that brings benefit to him ..."

Participant 8: "... so, sometimes we think, we want to correct people by force. Finally, nothing, even more damaging to the person. Today we try to think, change our minds, want to correct people with kindness, not with harshness, harsh punishments, but in a gentler manner, to appraise him. Possibly with that, he will turn out better than we hope for, nothing is certain. With this kind of situation, thus community service is good..."

\section{Conclusion}

The results of this study demonstrate that the sentence of community service order meets the takzir concept in Islam. Takzir is an explicit punishment not clearly explained of the types of punishment and offence in the al-Quran or al-Hadith. This punishment is aimed for retribution purposes and the maslahah of mankind and to keep at arm's length any mischief or damage that might occur if such offence is left unattended without control.

Furthermore, this study also shows that the implementation of community service order can achieve the objectives of punishment. This is so based on the outcome obtained from the studies in the West with such orders emplaced and implemented. With this, it is clear that such sentence of community service orders should be provided and implemented in the Syariah courts in Malaysia. However, this type of punishment is only appropriate for certain offences. Therefore, further research should be done to investigate these offences and the appropriate forms of community service orders meted out.

\section{References}

Abdullah, S. A. R. (2013). Community Service Orders in Sharia Court. Interview, 26 January.

Abu Rukhiyyah, M. (2010). al-Wajiz fi Ahkam al-Hudud wa al-Qisas wa al-Takzir (in Arabic). Jordan: Dar al-Nafaais.

Abu Zahrah, M. (t.th). al- ${ }^{c} U q u b a h:$ Al-Jarimah wa al- ${ }^{c}$ Uqubah fi al-Fiqh al-Islami (in Arabic). Dar al-Fiqh al- ${ }^{\mathrm{C}}$ Arabi.

Al-Azhari, B. I. A. (2011). al-Qardawi Fatwa Methode in Handling Recent Issues. Selangor: al-Hidayah Publication.

Ali, A. W. M. (2012). Community Service Orders in Sharia Court. Interview, 4 December.

Allen, R. (2008). Changing Public Attitudes to Crime and Punishment: Building Confidence in Community Penalties. Probation Journal, 55(4), 389-400. http://dx.doi.org/10.1177/0264550508096494

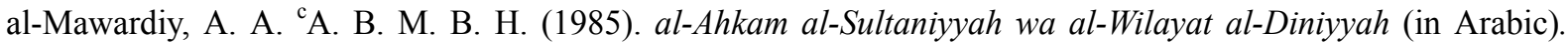
Beirut-Lubnan: Dar al-Kutub al- ${ }^{\mathrm{C}}$ Ilmiyyah.

al-Qur'an.

Altschuler, D. M., \& Armstrong, T. L. (2001). Reintegrating High-Risk Juvenile Offenders into Communities: Experiences and Prospects. Corrections Management Quarterly, 5(3), 72-88.

al-Zaydan, ${ }^{\mathrm{C}} \mathrm{A}$. A. (1998). al-Madkhal li Dirasah al-Syariah al-Islamiah (in Arabic) (16th reprint). Beirut-Lubnan: Muassasah al-Risalah.

al-Zaydan, ${ }^{\mathrm{C}}$ A. A. (2000). Nazarat fi al-Syariah al-Islamiah (in Arabic). Beirut-Lubnan: Muassasah al-Risalah.

Auda, J. (2010). Maqasid al-Sharicah as Philosophy of Islamic Law: A Systems Approach. Kuala Lumpur: Islamic Book Trust.

Awang, A. R. (2007). Criminal Concept in Islam and Recent Issues. In S. M. N. Alam, S. M. Hussain, Z. Kassim, 
A. Daud, W. M. S. dan Suzanti, \& A. Aziz (Eds.), Islamic Laws: Crimes, Evidence and Procedures (Vol. 13, pp. 3-26). Kuala Lumpur: Dewan Bahasa \&Pustaka.

Bahnasi, A. F. (1969). Nazariyyat fi al-Fiqh al-Jina'iy al-Islami: Dirasah Fiqhiyyah Muqaranah (in Arabic). (Second reprint). Kaherah: Muassasah al-Halabi wa Syawakah li al-Nasyri wa al-Tauzic .

Bahnasi, A. F. (1980). Mawqif al-Syariah min Nazariyyat al-Difa ${ }^{c}$ al-Ijtimac $i$ (in Arabic). (Second reprint). Dar al-Syuruq.

Bahnasi, A. F. (1983). Madkhal al-Fiqh al-Jina'iy al-Islami (in Arabic). (Third reprint). Dar al-Syuruq.

${ }^{\mathrm{c}}$ Awdah, ${ }^{\mathrm{c}}$ A. A. (2009). al-Tasyric al-Jina'i al-Islami (in Arabic). Kaherah: Dar al-Hadith.

Diggs, D. W., \& Pieper, S. L. (1994). Using Day Reporting Centres as an Alternative to Jail. Federal Probation, $58(1), 9-12$.

El-Muhammady, A. H. (2005). Criminal laws in Islam and the states enactments (2nd reprint). Selangor: Wadah Niaga (P) Ltd.

Ghani, M. Y. A. (2012). Community Service Orders in Sharia Court. Interview, 3 December.

Harris, P. M., Clear, T. R., \& Baird, S. C. (1989). Have Community Supervision Officers Changed Their Attitudes Toward Their Work? Justice Quarterly, 6(2), 233-246. http://dx.doi.org/10.1080/074188289 00090161

Hassan, A. W. A. (2012). Community Service Orders in Sharia Court. Interview, 23 October.

Johnson, P., \& Ingram, B. (2007). Windows of Opportunity for Unpaid Work? Probation Journal, 54(1), 62-69. http://dx.doi.org/10.1177/0264550507067047

Kiefli, A. G. (2012). Community Service Orders in Sharia Court. Interview, 10 October.

Leibrich, B. Y. J., Galaway, B., \& Underhill, Y. (1986). Community Service Sentencing in New Zealand: A Survey of Users. Federal Probation, 50, 55-64.

Mokhtar, M. F. H. (2012). Community Service Orders in Sharia Court. Interview, 12 October.

Nasohah, Z. (2008). Few Aspects of Criminal Punishment in Islam. In S. Z. M. Nor et al. (Eds.), Al-Syariah: Fiqh jenayah (Vol. 4, Chapter 1, pp. 1-21). Kuala Lumpur: Dewan Bahasa \& Pustaka.

O’Leary, V. (1987). Probation: A System in Change. Federal Probation, 51, 8-11.

Qawiy, Y. A. (2003). al-Jarimah wa al- ${ }^{c} I q a b$ fi al-Fiqh al-Islami (in Arabic). Beirut-Lubnan: Dar al-Kutub al- ${ }^{\mathrm{c}}$ Ilmiyyah.

Rahman, S. A. (2012). Community Service Orders in Sharia Court. Interview, 7 November.

Roslan, N. H. (2013, March 6). Alternative punishment: From the perspective of syarak and syariah criminal laws in Malaysia. Working paper of Convention on Syariah Criminal Laws Year 1434H/2013 AD. Organized by the Prosecution Division of the State Religious Affairs of Negeri Sembilan. Seremban, Negeri Sembilan.

Sharif, M. K. M. (2012). Community Service Orders in Sharia Court. Interview, 7 November.

Smith, P., \& Smith, W. A. (2005). Experiencing Community through the Eyes of Young Female Offenders. Journal of Contemporary Criminal Justice, 21(4), 364-385. http://dx.doi.org/10.1177/1043986205281722

Wahab, S. M. R. A. (2013). Community Service Orders in Sharia Court. Interview, 26 January.

Zain, A. M. (2012). Community Service Orders in Sharia Court. Interview, 10 October.

\section{Copyrights}

Copyright for this article is retained by the author(s), with first publication rights granted to the journal.

This is an open-access article distributed under the terms and conditions of the Creative Commons Attribution license (http://creativecommons.org/licenses/by/3.0/). 